\title{
STUDYING GROWTH CHARACTERISTICS OF YEAST STRAINS ON VEGETAL FERMENTATION MEDIA AND WITH VITAMIN SUPPLEMENTATION
}

\author{
J. MOLNÁR* and B. ÁsVÁNYI \\ Department of Food Science, Agricultural and Food Sciences, Széchenyi István University, \\ H-9200 Mosonmagyaróvár, Lucsony utca 15-17. Hungary
}

(Received: 1 November 2017; accepted: 23 March 2018)

\begin{abstract}
The primary purpose of these researches was to optimize single-cell protein (SCP) production process using Saccharomyces cerevisiae NCAIM Y.00200 and Kluyveromyces marxianus DSM 4908 strain, and then to analyse the changes in yield of single-cell protein final product using vitamin supplementation. To determine these values, the total sugar content of the fermentation medium, and the protein content of the yeast was determined. During our work, a particular attention was paid to the change of sugar content and yeast protein quantity. Besides, yield ( $\left.\mathrm{Y}_{\mathrm{x} / \mathrm{s}}\right)$ values, typical of the whole fermentation, were also measured. Protein yield, as the final product of fermentation, featured the efficiency of our work. The results of our optimized trial settings that were considered as control, using S. cerevisiae NCAIM Y.00200 and K. marxianus DSM 4908 strains, were compared with the results of vitaminsupplemented fermentation processes. On this basis, we can say that during our trials vitamin supplementation did not influence the final product yield of processes. The counted protein yields during fermentation were between $0.4-0.7 \mathrm{~g} \mathrm{~g}^{-1}$

Keywords: fermentation, single-cell protein, feed supplement, yeast strain, vitamin solution
\end{abstract}

Single-cell proteins were first applied during World War II in Germany and Russia to satisfy human protein demand. Nowadays, they are mainly sold as therapeutical product, and as baking yeast (MolNÁR et al., 2016). These days satisfying protein demand is a bigger and bigger problem, since the population is constantly increasing. In 19502.5 billion people lived on Earth, and the number of population will reach 9.15 billion by 2050 . It means a 2.25 billion people increase compared to 6.9 billion people in 2010. Along with it, the world's needs for food will increase by 70-90\%, which trends mainly towards calorie intake and meat consumption (Hungarian Ministry of Agriculture, 2016). To satisfy this increasing protein demand, one solution could be implanting SCP (single-cell protein) in human nutrition, apart from traditional protein sources (ANUPAMA \& RAVINDRA, 2000). Also, it is utilized as feed supplement to substitute animal feedstuff (KIM et al., 1998). Besides, it also has positive effect on the physiological state of the animal, most significantly in immune system stimulation (Li et al., 2016). Due to the prosperous content values of SCP, its utilization in feed industry, and the vitamin accumulating ability of yeasts, our purpose was to optimize the production process, and then to further analyse the change of final product yield using vitamin supplementation.

\footnotetext{
* To whom correspondence should be addressed.

Phone: +36 30 6074009; e-mail: molnar.judit@sze.hu
} 


\section{Materials and method}

Our experiments were done at the Department of Food Science, Agricultural and Food Sciences of Széchenyi István University, in Biostat A plus (Sartorius AG, Göttingen, Germany) type, in mixed and aerated fermenter with a reactor volume of $5 \mathrm{dm}^{3}$, employing batchwise fermentation. The applied concentration of anti-foam agent was $0.1 \mathrm{~cm}^{3} \mathrm{dm}^{-3}$. During fermentations the possible Crabtree effect did not emerge, there was no sign of its evolvement. The actual values of the set fermentation parameters (temperature, dissolved oxygen, agitation, and $\mathrm{pH}$ ) were monitored, and also the data were recorded by BIO PAT MFCS/DA (BIOPAT, Göttingen, Germany) software belonging to the equipment. The mathematical statistical analysis was done by MS Excel program (Microsoft, Redmond, WA, USA). Determining the significance level of optimized (control) process results and the vitamin supplemented process results was done by MicroCal Origin 3.0. (MicroCal Software, Northampton, MA, USA) software. According to our previous overview of the literature, S. cerevisiae yeast species are mainly applied during the production of alcohol and single-cell protein, therefore our chosen yeast strain was S. cerevisiae NCAIM Y.00200. K. marxianus yeast species are utilized mainly for solutions based on lactose to produce single-cell protein, although some of the literature deals with the same species utilized for vegetal based solutions to produce single-cell protein. Therefore, our other chosen yeast strain was K. marxianus DSM 4908. The S. cerevisiae NCAIM Y.00200 strain was acquired in lyophilised state from the National Collection of Agricultural and Industrial Microorganisms (Budapest). The freeze-dried K. marxianus DSM 4908 was from the strain collection of Deutsche Sammlung von Mikroorganismen und Zellkulturen (Braunschweig, Germany). We got the strains vacuum packaged, freeze-dried, in double ampoule. First the lyophilised preparation was rehydrated in saline $\left(6.5 \mathrm{~g} \mathrm{dm}^{-3} \mathrm{NaCl}\right)$ - during trials we used saline to make solutions because they have positive effect on the vital functions of the yeasts -, and then it was inoculated in YGC (yeast-glucose-chloramphenicol) broth and incubated at $25{ }^{\circ} \mathrm{C}$ for $48 \mathrm{~h}$. After that the yeasts were transferred from broths to YGC medium to prepare pure culture. After reviving the strains, the inoculum was prepared the following way: one lamella of yeast culture was washed into $50 \mathrm{~cm}^{3}$ saline $\left(6.5 \mathrm{~g} \mathrm{dm}^{-3}\right.$ $\mathrm{NaCl})$, which ensured the required degree of concentration $\left(10^{6} \mathrm{cell}^{-3}\right.$; ALBERTIN et al., 2011). Cell density was checked with Buerker-chamber cell counter, and the final concentration was set with dilution. Molasses for the fermentation media was provided by Györ Distillery Co. Ltd. Its most significant parameters are as follows: sugar content of $45.0^{\circ} \mathrm{Bx}, \mathrm{pH}$ of 7.35 , density of $1.38 \mathrm{~g} \mathrm{~cm}^{-3}$, dry matter value of $71.5 \mathrm{~g} / 100 \mathrm{~g}$, aerobian mesophyll germ count of $5.5 \times 10^{3} \mathrm{CFU} \mathrm{cm}{ }^{-3}$, yeast cell count of $3.1 \times 10^{2} \mathrm{CFU} \mathrm{cm}{ }^{-3}$. Also, molasses contain other useful components needed for the growth of yeast. Constituents of molasses recorded by SóLYOM and LÁszTity (1980) can be seen in Table 1.

Molasses were heat-treated $\left(80^{\circ} \mathrm{C} / 15 \mathrm{~min}\right)$ prior to use.

Corn steep liquor was provided by Kévés Llc., Soltvadkert, which was also heat-treated $\left(80{ }^{\circ} \mathrm{C} / 15 \mathrm{~min}\right)$. Also, the most important content parameters of corn steep liquor were determined as follows: $\mathrm{pH}$ of 4.1 ; dry matter content of $46.3 \mathrm{~g} / 100 \mathrm{~g}$, from which protein is $40.5 \mathrm{~g} / 100 \mathrm{~g}$; sugar content: monosaccharides of maximum $5 \%$, polysaccharides of maximum $20 \%$, lactic acid of 21-25\%; aerobic mesophilic germ count of $7.64 \times 10^{2} \mathrm{CFU} \mathrm{cm}^{-3}$, yeast cell count of $1.04 \times 10^{4} \mathrm{CFU} \mathrm{\textrm {cm } ^ { - 3 }}$. Other components present in corn steep liquor needed for growth of yeast are summarized in Table 2 (Demain \& Solomon, 1986). 
Table 1. Constituents of molasses (Sólyom \& LÁszTity, 1980)

\begin{tabular}{lc}
\hline Components & Concentration $(\%)$ \\
\hline Water content & 16.5 \\
Saccharose content & 51 \\
Nitrogen-free non-sugars: & 1 \\
Invert sugar & 1 \\
Raffinose & 19 \\
Nitrogenous components: & \\
Free and combined acids & \\
Colouring matters & \\
Bios materials & 11.5 \\
Others & 100 \\
Minerals (ash components) & \\
Total & \\
\hline
\end{tabular}

Table 2. Identifying the contents of corn steep liquor (Demain \& Solomon, 1986)

\begin{tabular}{lc}
\hline Components & Concentration \\
\hline Dry matter content & $50 \%$ \\
Protein content & $24 \%$ \\
Carbohydrate & $5.8 \%$ \\
Fat & $1 \%$ \\
Fibre content & $1 \%$ \\
Ash content & $8.8 \%$ \\
Biotin & $0.88 \mathrm{mg} \mathrm{kg}^{-1}$ \\
Pyridoxine & $19.36 \mathrm{mg} \mathrm{kg}^{-1}$ \\
Thiamine & $0.88 \mathrm{mg} \mathrm{kg}^{-1}$ \\
Panthotenic acid & $74.8 \mathrm{mg} \mathrm{kg}^{-1}$ \\
Free amino acids & $4.9 \%$ \\
\hline
\end{tabular}

For each fermentation, 2-2 $\mathrm{dm}^{3}$ of both molasses and corn steep liquor solution was used, with triple dilution to set the proper carbo-hydrate content: $1.345 \mathrm{~cm}^{3}$ of saline $\left(6.5 \mathrm{~g} \mathrm{dm}^{-3} \mathrm{NaCl}\right)$ was added to the available $655 \mathrm{~cm}^{3}$ of molasses and corn steep liquor, so the final fermentation media used for our experiments were aquired.

First, fermentation parameters of $K$. marxianus DSM 4908 and S. cerevisiae NCAIM Y.00200 [25-30 ${ }^{\circ} \mathrm{C} ; 4.5-5.5 \mathrm{pH}$ value; $100-200-300-400$ r.p.m.; 1-1.5 v.v.m. (vessel volumes per min)] on corn steep liquor and molasses were optimized to produce single-cell protein. These were chosen mainly according to the scientific literature (CÁCERES-FARFÁn et al., 2008; EL-Gendy et al., 2013; TrAviÑA-MuÑOZ et al., 2013). The optimized (control) values are given in Table 3.

The optimized fermentation process was vitamin supplemented to study the effect of the vitamin solution on the final product yield. Prior to our trials, we had studied the scientific literature, where enrichment was employed during fermentation processes to supplement micronutrients or vitamins (Furutani et al., 1953; Simon \& Szilágyi, 2003; Champagne et al., 2010). Vitamin supplementation according to Wickerham was chosen due to its beneficial effect on microbial growth. Constituents of $100 \mathrm{~cm}^{3}$ vitamin stock solution: $0.2 \mathrm{mg}$ folic acid, 
$0.2 \mathrm{mg}$ biotin, $40 \mathrm{mg}$ Ca-pantothenate, $200 \mathrm{mg}$ inositol, $40 \mathrm{mg}$ nicotinic acid, $20 \mathrm{mg} p$-aminobenzoic acid, $40 \mathrm{mg}$ pyridoxine- $\mathrm{HCl}, 40 \mathrm{mg}$ thiamine- $\mathrm{HCl}$, and $20 \mathrm{mg}$ riboflavin (FurUTANI et al., 1953). Our study extends solely to the effect of vitamin supplementation on the yield of the final product.

Table 3. The optimized (control) fermentation parameters

\begin{tabular}{lcccc}
\hline & $\mathrm{A}$ & $\mathrm{B}$ & $\mathrm{C}$ & $\mathrm{D}$ \\
\cline { 2 - 5 } & \multicolumn{3}{c}{$\begin{array}{c}\text { Experimental } \\
\text { setting* }\end{array}$} \\
\hline Temperature ( $\left.{ }^{\circ} \mathrm{C}\right)$ & 30 & 30 & 30 & 30 \\
Agitation (r.p.m.) & 200 & 400 & 300 & 300 \\
Airflow rate (v.v.m.) & 1.5 & 1.5 & 1.5 & 1.5 \\
pH & 5.5 & 5.5 & 4.5 & 4.5 \\
\hline
\end{tabular}

*: Saccharomyces cerevisiae NCAIM Y.00200 in molasses (A) and corn steep liquor (B) media, and Kluyveromyces marxianus DSM 4908 in molasses (C) and corn steep liquor (D) media

After reaching the set parameters, the inoculum was injected into the raw material solution. The process was carried out for 72 hours, and several samples were taken at the $0^{\text {th }}$, $24^{\text {th }}, 48^{\text {th }}$, and $72^{\text {nd }} \mathrm{h}$. The experiment was repeated with the supplementation of $1 \mathrm{~cm}^{3} \mathrm{dm}^{-3}$ vitamin fermentation medium according to Wickerham of the raw material. Total sugar content of fermentation medium and yeast-derived protein content were determined. In every case there were three parallel measurements done. Protein yield was calculated from the yeast growing relations. For determining the protein content, $5 \mathrm{~g}$ purged, washed, and dried at $105^{\circ} \mathrm{C}$ samples were used. All sugar contents were determined also from dried samples by Luff-Schoorl method (Pomeranz \& Meloan, 2000), after inverting the complex sugars. The nitrogen content was determined by Kjeldahl method (Pomeranz \& Meloan, 2000). The yeast-derived protein content was counted by subtracting nitrogen content of filtered fermentation broth from the nitrogen content of yeast.

\section{Results and discussion}

\subsection{Total sugar content of the fermentation medium and protein content of yeast measured for optimized (control) and vitamin supplemented fermentation processes}

Total sugar content of the fermentation medium and protein content of yeast were measured from the samples taken at the $0^{\text {th }}, 24^{\text {th }}, 48^{\text {th }}$, and $72^{\text {nd }} \mathrm{h}$ during optimized (control) and vitamin supplemented fermentation processes. These results are summarised in Tables 4 and 5.

Results given in Table 4 show that A and $C$ trial settings had $53.4 \pm 0.4 \mathrm{~g} / 100 \mathrm{~g}$ initial total sugar content at the $0^{\text {th }}$ hour, while B and D trial settings had $24.3 \pm 0.5 \mathrm{~g} / 100 \mathrm{~g}$ initial values at the same time. These results changed to $0.2 \pm 0.1-1.9 \pm 0.4$ by the $72^{\text {nd }}$ hour. Protein contents of yeast, given in Table 5 , were $4.5 \pm 0.4 \mathrm{~g} / 100 \mathrm{~g}$ at the $0^{\text {th }}$ hour, while they were $20.5 \pm 0.5-30.5 \pm 0.3 \mathrm{~g} / 100 \mathrm{~g}$ at the $72^{\text {nd }} \mathrm{h}$. We want to highlight that there was a significant $(\mathrm{P}<0.05)$ difference between the optimized (control) and vitamin supplemented trials of $\mathrm{A}$ and $\mathrm{C}$ trial settings at the $72^{\text {nd }} \mathrm{h}$. 
MOLNÁR \& ÁSVÁNYI: STUDYING GROWTH CHARACTERISTICS OF YEASTS
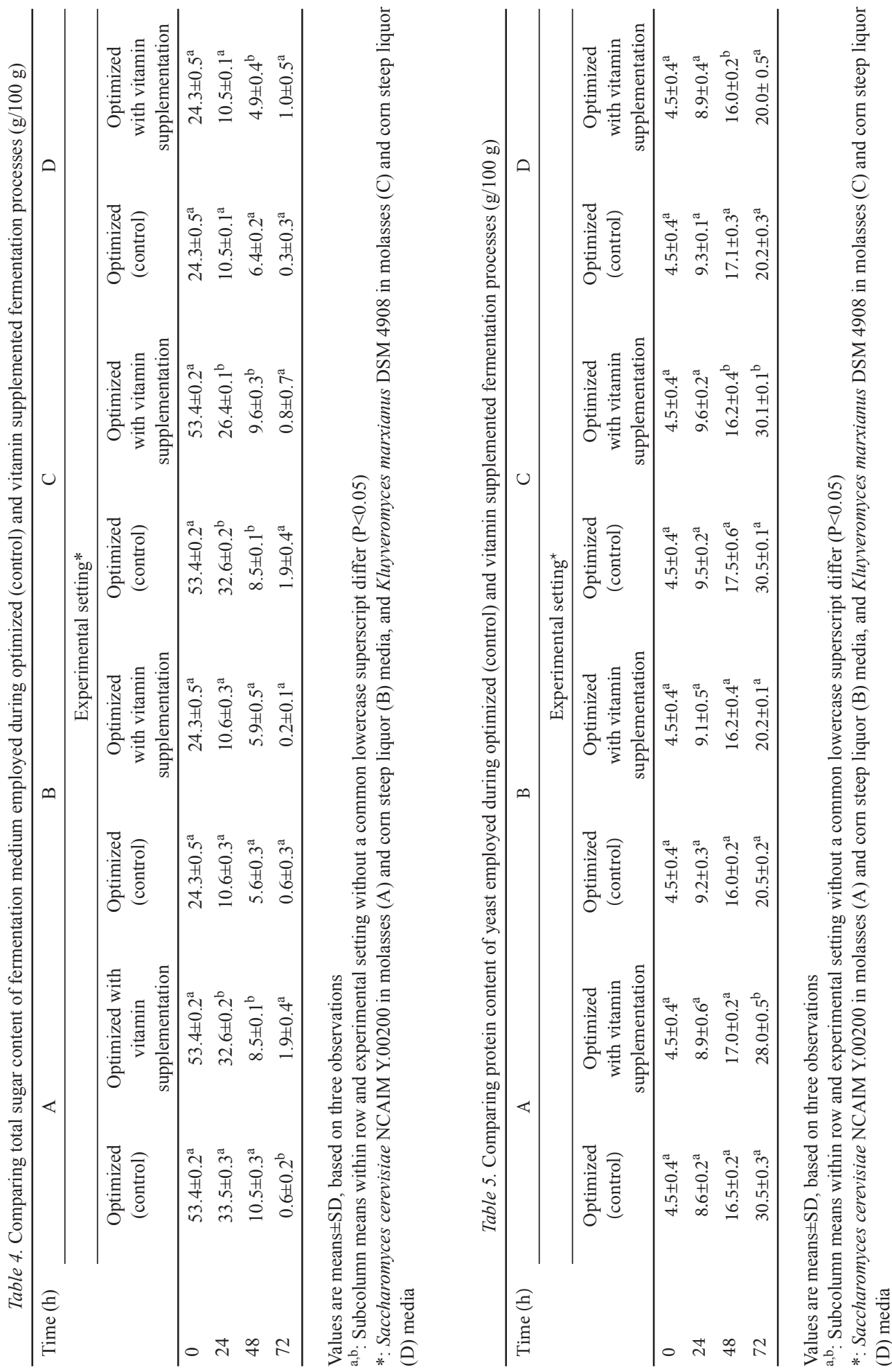


\subsection{Protein yield $(Y x / s)$ determinations of optimized (control) and vitamin supplemented fermentation processes}

Protein yield $\left[\mathrm{Y}_{\mathrm{x} / \mathrm{s}}\left(\mathrm{g} \mathrm{g}^{-1}\right)\right]$ values can be calculated from the functional relationship of the change of the sugar content of the fermentation medium and the cell mass protein measured during fermentation trials.

Based on the protein yield values given in Table 6, vitamin supplementation did not influence the final product yield of the trial settings significantly. TRIGUEROS and co-workers (2016) did fermentation of S. cerevisiae var. boulardii on cheese whey, where their biomass yield $\left(\mathrm{Y}_{\mathrm{x} / \mathrm{s}}=0.5 \mathrm{~g} \mathrm{~g}^{-1}\right)$ was almost equal with our calculated values, whereas there was no significant difference compared to the control. ÁsVÁNYI (2005) also studied biomass yields during his experiments with $K$. lactis and $K$. marxianus yeast species, where the values varied between $Y_{\mathrm{x} / \mathrm{s}}=0.2 \mathrm{~g} \mathrm{~g}^{-1}$ and $\mathrm{Y}_{\mathrm{x} / \mathrm{s}}=0.6 \mathrm{~g} \mathrm{~g}^{-1}$, respectively.

Table 6. Yeast-derived protein yield values $\left[\mathrm{Y}_{\mathrm{v} / \mathrm{s}}\left(\mathrm{g} \mathrm{g}^{-1}\right)\right]$ in optimized (control) fermentation process and in the fermentation process involving vitamin supplementation

\begin{tabular}{lcc}
\hline Trial* $^{*}$ & Optimized $\left(\right.$ control) $^{\mathrm{a}}$ & Vitamin supplementation $^{\mathrm{a}}$ \\
\hline $\mathrm{A}$ & 0.5 & 0.4 \\
$\mathrm{~B}$ & 0.7 & 0.6 \\
$\mathrm{C}$ & 0.5 & 0.5 \\
$\mathrm{D}$ & 0.6 & 0.7 \\
\hline
\end{tabular}

*: Saccharomyces cerevisiae NCAIM Y.00200 in molasses (A) and corn steep liquor (B) media, and Kluyveromyces marxianus DSM 4908 in molasses (C) and corn steep liquor (D) media. ${ }^{\text {a }}$ : There was no significant difference in protein yields at $\mathrm{P}<0.05$.

\section{Conclusions}

Results given in Table 4 clearly show that during optimized (control) and vitamin supplemented fermentation processes the total sugar content of the fermentation medium significantly decreased and was practically consumed by the $72^{\text {nd }}$ hour. Accordingly, we can conclude the sugar conversion of yeast. Yeast protein content values, given in Table 5, increased by the $72^{\text {nd }} \mathrm{h}$ of the fermentation in each trial setting, which also proves the utilization of yeast fermentation medium.

According to the obtained protein yield values $\left(0.4-0.7 \mathrm{~g} \mathrm{~g}^{-1}\right)$, which are in accordance with several scientific publications, we came to the conclusion that vitamin supplementation do not have a significant influence on final product yield.

\section{References}

Albertin, W., Marullo, P., Aigle, M., Dillmann, C., De Vienne, D., Bely, M. \& Sicard, D. (2011): Population size drives industrial Saccharomyces cerevisiae alcoholic fermentation and is under genetic control. Appl. Environ. Microbiol., 77, 2772-2984.

Anupama \& Ravindra, P. (2000): Value-added food: Single cell protein. Biotechnol. Adv., 18, 459-479.

ÁsvÁNYI, B. (2005): Egysejtfehérje-elöállitás optimalizálása Kluyveromyces törzsek alkalmazása esetén. (Optimization of single-cell protein production using Kluyveromyces strains). Theses of doctoral (Ph.D.) dissertation. Mosonmagyaróvár. pp. 6-136. 
Cáceres-Farfán, M., Lappe, P., Larqué-Saavedra, A., Magdub-Méndez, A. \& Barahona-Pérez, L. (2008): Ethanol production from henequen (Agave fourcroydes Lem.) juice and molasses by a mixture of two yeasts. Bioresour. Technol., 99, 9036-9039.

Champagne, C.P., Tompkins, T.A., Buckley, N.D. \& Green-Johnson, J.M. (2010): Effect of fermentation by pure and mixed cultures of Streptococcus thermophilus and Lactobacillus helveticus on isoflavone and B-vitamin content of a fermented soy beverage. Food Microbiol., 27, 968-972.

Demain, A.L. \& Solomon, N.A. (1986): Manual of industrial microbiology and biotechnology. American Society for Microbiology, Washington, D. C., pp. 1-466.

El-Gendy, N.S., Madian, H.R. \& Abu Amr, S.S. (2013): Design and optimization of a process for sugarcane molasses fermentation by Saccharomyces cerevisiae using response surface methodology. Int. J. Microbiol., Article ID 815631, 9.

Furutani, Y., Betz, F.R. \& Hedrick, R.L. (1953): Vitamin requirements of Hansenula yeasts in relation to their phylogeny. J. Bacteriol., 65, 276-280.

Hungarian Ministry of Agriculture (2016): Magyarország élelmiszergazdasági programja 2016-2050 (Hungary’s Food Program 2016-2050), pp. 1-56.

KiM, J.K., TAK, K.T. \& Moon, J.H. (1998): A continuous fermentation of Kluyveromyces fragilis for the production of a highly nutritious protein diet. Aquacult. Eng., 18, 41-49.

Li, X., Xu, W., Yang, J., Zhao, H., Pan, C., Ding, X. \& Zhang, Y. (2016): Effect of different levels of corn steep liquor addition on fermentation characteristics and aerobic stability of fresh rice straw silage. Anim. Nutr., 2, 345-350.

MolnÁr, J., MolnÁr, R. \& KóróDI, Gy. (2016): Analysis of resupply of energy for workforce accomplishing long term damage cleanup duties. Academic and Applied Research in Military and Public Management Science (AARMS), 15, 223-229.

Pomeranz, Y. \& Meloan, E.M. (2000): Food analysis. Aspen Publishers, Inc., Gaithersburg, pp. 636, $736-744$.

Simon, L. \& SzILÁGYi, M. (2003): Mikroelemek a táplálékláncban (Microelements in food-chain). Bessenyei György Könyvkiadó. Nyíregyháza, pp. 58-66.

Sólyom, L. \& LÁsztity, R. (1980): A melasz (Molasses). Mezőgazdasági Könyvkiadó, Budapest, p. 20.

Traviña-Muñoz, D., PÁez-Lerma, J., Rutiaga-Quiñones, O., Gschaedler-Mathis, A. \& Soto Cruz, N. (2013): Production of biomass of Saccharomyces cerevisiae and Torulaspora delbrueckii changing aeration and agitation condition in batch reactor. 17th National Congress of Biotechnology and Bioengineering, June 2328. 2013. Cancún. Mexico.

Trigueros, D.E.G., Fiorese, M.L., Kroumov, A.D., Hinterholz, C.L., Nadai, B.L. \& Assuncao, G.M. (2016): Medium optimization and kinetics modelling for the fermentation of hydrolyzed cheese whey permeate as a substrate for Saccharomyces cerevisiae var. boulardii. Biochem. Eng. J., 110, 71-83.

Open Acces statement. This is an open-access article distributed under the terms of the Creative Commons Attribution 4.0 International License (https://creativecommons.org/licenses/by/4.0/), which permits unrestricted use, distribution, and reproduction in any medium, provided the original author and source are credited, a link to the CC License is provided, and changes - if any - are indicated. (SID_1) 